\title{
Morfofunctional parameters in judo's fight
}

\author{
Ítalo Sérgio Lopes Campos ${ }^{1 *}$, Yan Sobral Campos ${ }^{1}$, Hector Andrés Páez ${ }^{1,2}$, Alam dos Reis \\ Saraiva $^{3}$, Amauri Gouveia ${ }^{1}$
}

ARTIGO ORIGINAL | ORIGINAL ARTICLE

\begin{abstract}
Considering the complexity of judo and the ample energy and neuromuscular demands, a whole process of competitive preparation must be directed to different physical capacities allowing the athlete to perform his combat actions with the best suitability possible. Mapping the behaviour of a judo athlete from observations of behaviour units in a real fighting situation would be a way of trying to identify the best topography or the best "aptitude" to achieve victory. The present investigation analysed the judo from the interactions of a real competition situation, aiming to verify, between winners and losers, possible differences or correlations between anthropometric parameters, motor performance and functional behaviours in a competitive situation. The results showed that: a) the experience is decisive between winning or losing; b) leg techniques are the most used between winners and losers, and losers use them more frequently; c) there are different strategies between fights; d) The energy cost in judo depends on the configuration of the fights. It is believed that such results can help coaches and athletes in guiding and rationalizing the training process in relation to performance determinants in judo.

Keywords: martial arts, judo, training, performance, energy cost.
\end{abstract}

\section{INTRODUCTION}

A Judo is one of the most popular fighting sports practiced in the western world. Regarding its technical aspect, this basically predicts the use of movements from the use of force and the weight of the opponent against himself (Watson, 2011); therefore, the application of throws is based on the principle of the levers where the kuzushi (opponent's imbalance), tsukuri (strike entry) and kake (projection) are used (Santos, 2013). In short, judo combines physical abilities with good technical-tactical and psychological preparation, with extensive energy and neuromuscular demands in constant variations, requiring good combination of aerobic, anaerobic, strength and flexibility (Detanico \& Santos, 2012; Nagata, 2010).

In the competitive aspect, a judo fight is characterized as an intermittent effort, also requiring complex skills of high intensity and dynamics, combined with an excellent fighting tactic (Franchini et al., 2011). In this way, taking the initiative to grab, hold or compete for a better position of movement, within the limits of the rules, can be determinant to lead the athlete to a more effective performance in the competition. This justifies a whole process of competitive preparation directed to different physical capacities to allow the athlete to perform his techniques/tactics of fight with better physical conditioning (Franchini, et al., 2011).

The level of performance of judo, in terms of energy expenditure, has been subject of research (Artioli et al., 2012; Drigo et al., 1996; Franchini, et al., 2008; Franchini et al., 2011; Julio et al., 2016). Such studies aimed to define physiological profiles of athletes using laboratory tests to simulate some demands of the fight in judo. Through the observation of video recording of athletes in competitive situations (Ando et al., 2016; Marcon et al., 2010; Miarka, 2014) it is possible to identify at least two control strategies, one characterized by a more aerobic profile (resistance) and one with a more anaerobic profile (explosion) (Gariod et al., 1995). The fight time is related to these profiles. In the first

\footnotetext{
Manuscript received at February $6^{\text {th }} 2017 ;$ Accepted at March $3^{\text {rd }} 2017$

${ }^{1}$ Universidade Federal do Pará, Belém-Pará, Brazil

${ }^{2}$ Universidad Santo Tomás Seccional Bucaramanga, Bucaramanga, Santander, Colombia

${ }^{3}$ Instituto Federal do Pará, IFPA, Belém-Pará, Brazil

* Corresponding author: Rua Augusto Corrêa, 1 - Guamá, Belém - PA, 66075-110, Brasil. E-mail: italo@ufpa.br
} 
situation the fight can develop for a few minutes and in the second only for a few seconds. We consider that the qualitative analysis of the energy cost of a judo match, combined with training regime data and morphofunctional parameters of athletes, may be useful in identifying which elements (morphofunctional, technical and tactical) influence the energy expenditure and the winning or losing result.

Based on these assumptions, to map the behaviour (not always so explicit) of a judo athlete from observations of behaviour units, in a real fighting situation, would be a way of trying to identify the best topography or the best "aptitude" to achieve victory. From this perspective it is possible to think of a functional analysis of the fight in judo from the elaboration of an ethogram. According to Lehner (1996), this type of process aims to identify levels of organization of behaviour and how these tend to occur in a subject in a given environmental situation in terms of common characteristics, dyads, behaviour types and body involvement (frequency and duration).

In order to deepen the knowledge, specifically with regard to morphofunctional parameters, the present study aims to analyse judo from the quantitative and qualitative interactions of an ethogram in a real competition situation, prospecting to verify between winners and losers, possible differences or correlations between anthropometric parameters (Body mass, height, body mass index/BMI), motor performance (handgrip strength, lumbar force, thoraco-lumbar flexibility) and functional conducts in real competition situations.

\section{METHOD}

The research is an quasi-experimental observational study and was initiated in accordance with the approval of the Ethics Committee in Research of the Federal University of Pará (UFPA), resolution $\mathrm{n}^{\circ}$ 1.622.308. The confirmation of the participant in the study was determined by the signing of the Informed Consent Form (TCLE) prepared for this purpose.

\section{Sample}

From a sample originally composed of 15 male judo athletes, all ranked and volunteers, were pre-selected extremes in terms of higher and lower colocation in the ranking of the Judo Federation of Pará. In the end, twelve athletes with competitive experience were followed, ranging from regional to national and usual training regime. As an inclusion/exclusion criterion, recruited participants should not present any evidence of cardiovascular disease, history of endocrine disorders or hypertension, or even the use of steroid drugs. Regarding the technical capacity, all the athletes presented at least the purple range.

\section{Instruments and Procedures}

Participants were assessed at their training sites, preliminary to the completion of an anamnesis. At the same place, morphofunctional measures were performed, including anthropometry (weight, height and BMI) and physical tests (manual grip strength, lumbar force and thoraco-lumbar flexibility). Subsequently, participants were informed of the need to be monitored later in a real judo competition situation where they would be filmed for further observations and analysis. With the consent of the Judo Federation, the participants were accompanied at a competitive event in the city of Paragominas. All information collected, related to anamnesis, anthropometry and motor tests, were recorded in a specific worksheet built for this purpose.

\section{Anamnesis}

All study participants completed an anamnesis with general information on identification, health, medication use, and sports routine. This instrument was previously completed to carry out the anthropometric measurements and the motor tests.

\section{Anthropometric Measurements}

To measure body mass, a digital scale (Incoterm, 28010, Brazil) was used, with a capacity of $150 \mathrm{~kg}$, with an accuracy of up to 100 grams, while the height measurement was done using a tape measure (Fiber Glass), fixed to the 
wall, to the nearest millimetre. Both protocols were applied according specific standardization (França \& Vívolo, 1994). From the measures of mass and height, the Body Mass Index (BMI) was calculated and classified from the $\mathrm{kg} / \mathrm{m}^{2}$ ratio (WHO, 2003).

\section{Motor Testing}

Measurement of hand grip strength was determined by manual dynamometry (Jamar, USA) in kilogram-force, according to standardization (Caporrino et al., 1998). Lumbar strength was measured with the lumbar model dynamometer (PC5039B Medical Iberica, Spain) according to standards (Mathews, 1980). For the measurement of thoraco-lumbar flexibility, the linear test of sit and reach was used, through the Well's Bank, according to specific standardization (Guedes \& Guedes, 2006).

Table 1

Categorization, description and standardization of the elements to be observed and analysed in the filming.

\begin{tabular}{ll}
\hline Category & \multicolumn{1}{c}{ Description } \\
Preparation & $\begin{array}{l}\text { Time of movement and observation of the } \\
\text { athletes (discrete or non-existent } \\
\text { contacts). There may be movement of the } \\
\text { athletes. }\end{array}$ \\
\hline \multirow{3}{*}{ Grab } & $\begin{array}{l}\text { Time of fight where the hand contact in } \\
\text { the opponent's kimono manifests } \\
\text { intermittently, due to the foot race (with } \\
\text { one or both hands). }\end{array}$ \\
\hline Hit & $\begin{array}{l}\text { Realization of the technique in standing } \\
\text { combat (Leg, Arm, Hip). Scams that were } \\
\text { effective or not. }\end{array}$ \\
\hline Fall & $\begin{array}{l}\text { Situation where the athlete analysed falls } \\
\text { by force of a blow, voluntarily or by a } \\
\text { technical error. It is possible that both } \\
\text { athletes fall due to the application of a } \\
\text { technique of sacrifice. }\end{array}$ \\
\hline Ground fight & $\begin{array}{l}\text { Ground combat time (immobilization, } \\
\text { bottlenecks, arm switches and finishing). }\end{array}$ \\
\hline \multirow{2}{*}{ Pause } & $\begin{array}{l}\text { Intermittent and varied time of } \\
\text { interruption of the fight, which occur in } \\
\text { the course of the combat by orientation of } \\
\text { the arbitration (matte). }\end{array}$ \\
\hline Fight time & Total fight time \\
\hline Outcome & How the fight was ended. \\
\hline Results & Won / lost \\
\hline
\end{tabular}

\section{Film of the fighting}

The athletes were filmed (Sony DCR-SX20, Japan) in two judo matches, regardless of previous defeat. The recordings were made from the side of the combat area, with the full vision and full timing of the fight (Miarka, 2014). The material collected and transcribed on a spreadsheet comprised the video recording of twenty-three battles with an initial duration of three minutes each.

\section{Description and standardization of observation}

The categories analysed in each fight, as well as the description of the videos are presented in table 1. It was decided to adapt some categories from the model of situational phases of the fight proposed by Miarka (2014). Finally, the athletes were classified in winners or losers in relation to the first fight.

\section{Qualitative analysis of the energy cost of the figth}

Considering the difficulty to establish a physiological response to quantify the intensity in judo due to the unpredictability, dynamics and different arrangements of the fight (Franchini et al., 2008; Julio, 2015; Miarka, 2014;), the qualitative index of the energy cost of fight (IQCE) was elaborated from the available values in the literature and analysed elements. For this purpose, the study by Franchini et al. (2008), on the contributions of $\mathrm{VO}_{2}\left(\mathrm{ml} . \mathrm{kg} \cdot \mathrm{min}^{-1}\right)$ and total energy cost $(\mathrm{KJ})$ for the execution of three different judo techniques Morote-seoi-nage (arm), $273 \mathrm{KJ}$; Harai-goshi (hip), $259 \mathrm{KJ}$ and o-uchi-gari (leg), $237 \mathrm{KJ}$. The IQCE was calculated referencing the value of the leg strike (lower energy cost) as 100 percent, and dividing the values of the other throws by this one and multiplying by 10 , in order to facilitate the application. Thus, the division of the total energy costs of arm blows $(273 \mathrm{KJ})$ and hip $(259 \mathrm{KJ})$, the total cost of the leg strike $(237 \mathrm{KJ})$, generated the percentage values on the leg strike respectively: 1.15 for arm; 1.09 for hip; 1 for leg. To give authenticity to the numerical values found, they were faced with the $\mathrm{VO}_{2}$ values $\left(\mathrm{ml} \cdot \mathrm{kg} \cdot \mathrm{min}^{-1}\right)$ of the respective strokes (arm, $33.71 \mathrm{ml}$, hip, 32.28 $\mathrm{ml}$ and leg, $29.97 \mathrm{ml}$ ) available in the same study of Franchini et al. (2008), and converted to Liters $\left(\right.$ L. $\left.\mathrm{min}^{-1}\right)$ using the mean body mass of the participants $(81.21 \mathrm{~kg})$. This procedure was used to confirm the maintenance of the energy order of the throws through $\mathrm{VO}_{2}\left(\mathrm{~L} \cdot \mathrm{min}^{-1}\right)$. 


\section{Statistical analysis}

After normality test (Komoroff-smirnoff) the morphofunctional data and sports regime were analysed through one-way ANOVA (result of the first fight) or Kruskal-Wallis test (Anova in Ranks). The description of the Fighting was analysed by two-way ANOVA (the result of the first fight $\times$ fights $\left(1^{\text {st }}\right.$ and $\left.2^{\text {nd }}\right)$.) The anthropometric and motor parameters were correlated through Pearson's correlation coefficient. The differences in results between the first and second fight were analysed by Kendall's Tau correlation coefficient.

\section{RESULTS}

Table 2 shows the anthropometric values, the usual training regime and the results of the motor tests.

Table 2.

General characterization of the sample in terms of total values, mean and standard deviation in relation to anthropometric values, habitual training regime and motor tests for winners and losers and for the total sample.

\begin{tabular}{cccc}
\hline Category & Winners & Losers & Total \\
\hline Age & $20.5 \pm 3.82$ & $22.75 \pm 7.68$ & $21.25 \pm 5.04$ \\
\hline Weight & $81.21 \pm 26.10$ & $80.72 \pm 28.06$ & $81.05 \pm 25.84$ \\
\hline Height & $173.93 \pm 6.36$ & $168.75 \pm 8.34$ & $172.20 \pm 7.89$ \\
\hline BMI & $26.3 \pm 6.13$ & $28 \pm 7.99$ & $26.86 \pm 6.43$ \\
\hline Practice time & $9.75 \pm 5.80^{*}$ & $6.25 \pm 0.81$ & $8.58 \pm 4.89$ \\
\hline Weekly training (days) & $4 \pm 0.90$ & $4.25 \pm 1.5$ & $4.08 \pm 1.08$ \\
\hline Daily training (hours) & $2.12 \pm 0.44$ & $1.87 \pm 0.40$ & $2.04 \pm 0.42$ \\
\hline handgrip strength (Kgf) & $107.62 \pm 9.46$ & $100.75 \pm 18.82$ & $105.33 \pm 12.50$ \\
\hline Lumbar force (Kgf) & $155.37 \pm 24.32$ & $136 \pm 23.97$ & $148.91 \pm 24.61$ \\
\hline Flexibility (cm) & $34.25 \pm 7.41$ & $34 \pm 6.35$ & $34.16 \pm 6.93$ \\
\hline
\end{tabular}

* Significant for $\mathrm{p}<0.05$ (Kruskal Wallis)

Despite the differences found between winners and losers in terms of mass and height and BMI, they were not statistically significant. Regarding the usual training regime, the analysis showed that there was a statistically significant difference $[\mathrm{H}=4.810,(\mathrm{p}=0.028)]$ in the comparison of the average time of practice between winners and losers. As for the analysis of the motor tests, it was observed that winners present higher values for all the questions, however, these values were not statistically significant.

Data correlation analysis (Pearson) identified the existence of significant correlation coefficients $(p<0.05)$ between anthropometric and motor parameters. It was observed that body mass presented a positive correlation with BMI ( $\mathrm{r}$ $=0.846, \mathrm{p}<0.000)$ and with handgrip strength $(\mathrm{r}=0.525, \mathrm{p}=0.040)$ and negative correlation with flexibility $(\mathrm{r}=-0.641, \mathrm{p}=0.012)$. It was also observed that the height presented a positive correlation with handgrip strength $(r=0.697$, $p$ $=0.006)$. In relation to $\mathrm{BMI}$, it correlated positively with handgrip strength $(\mathrm{r}=0.608, \mathrm{p}=$ $0.018)$ and negatively with flexibility $(r=-0.725$, $\mathrm{p}=0.004)$. The handgrip strength had a positive correlation with lumbar force $(r=0.644, p=$
0.012 ) and negative correlation with flexibility ( $\mathrm{r}$ $=-0.635, \mathrm{p}=0.013)$. It was also identified a negative correlation between lumbar force and flexibility $(r=-0.635, p=0.013)$.

\section{Description of the fights}

Regarding the results of the temporal analysis of the fight in the competition, it was observed that there was no difference between the categories analysed between the first and the second fight, being the distribution of the elements preparation, footprint, pause, ground fight, similar between fights and between winners and losers. It was observed that both in the first and in the second fight, the preparation time was similar between winners and losers. However, in the grab dispute category, losers presented average values higher than the winners in the second fight. In relation to the pause time, losers presented values superior to the winners, both in the first and in the second fight, and in the second fight these values were higher. As for the fight time on the ground, it was observed a change in the configuration of the fights, considering that in the first fight the winners presented average values superior to the losers, whereas in the second fight this fact has inverted 
considerably. As for the results of the functional analysis of the fight, a similar distribution was also observed between the elements of the first and the second fight between winners and losers, with a predominance of the use of the throws of legs in relation to the other blows. Leg strikes showed significant differences between winners and losers $\left[\mathrm{F}_{(1,18)}=6.168, \mathrm{p}=0.023\right]$, with no difference between the fights $\left[\mathrm{F}_{(1,18)}=0.486\right]$ and no interaction between the factors $\left[\mathrm{F}_{(1,18)}=\right.$ 1.805]. In relation to the losers it was observed a decrease in the use of the arm strikes in the second fight compared with the first fight.

As for the outcome of the two fights, it was observed that winners were more effective than losers in relation to the number of ippon. On the other hand, it was observed a decrease of such effectiveness in the second fight, considering the decrease in the number of ippon in favour of other forms of outcome for the termination of the fight.

Regarding the results of the energy cost of the fights, the data found revealed that in the first fight the energy cost of the fight is lower for winners than for losers. In the second fight it was observed an inversion of the energy cost, with winners presenting higher values in relation to losers.

A Pearson correlation analysis was performed to verify the existence of a linear relationship between functional elements and the outcome of the fight (win or lose); elements among themselves; fight elements and morphofunctional parameters; elements of the fight and training regime. Thus, it was observed that the leg strike had a positive correlation with the outcome of the fight $(r=0.663, p=0.019)$. In relation to the time of the fight, this one presented a positive correlation with the arm strike $(r=0.759, p=$ $0.011)$ and with the leg strike $(r=0.659, p=$ 0.0380). The arm strike also showed a positive correlation with the fall $(r=0.602, p=0.038)$ and with the outcome of the fight $(r=0.602, p=$ 0.038). The fall presented a positive correlation with the leg strike $(r=0.635, p=0.026)$ and with the outcome $(r=0.589, p=0.044)$. Grabbing showed a positive correlation with lumbar force $(r=0.666, p=0.016)$ and with practice time $(r=0.576, p=0.050)$. The pause presented a positive correlation with the practice time $(\mathrm{r}=0.717, \mathrm{p}=0.009)$. The leg strike had a positive correlation with the mass $(r=0.668, p$ $=0.018) \mathrm{A}$ positive correlation between handgrip strength and footprint $(r=0.682, p=$ 0.030 ) and negative correlation between handgrip strength and weekly training $(\mathrm{r}=$ $0.575, \mathrm{p}=0.051)$ and between handgrip strength and training time $(\mathrm{r}=-0.685, \mathrm{p}=0.014)$. Likewise, lumbar force presented a negative correlation with weekly training $(\mathrm{r}=-0.567, \mathrm{p}=$ $0.055)$ and with training time $(r=-0.777, p=$ 0.003), as well as flexibility showed a negative correlation with the handgrip strength $(\mathrm{r}=$ 0.664, $p=0.036$ ).

\section{DISCUSSION}

\section{Training time and morphofunctional factors}

Practice time implies acquired experience. It was observed in the data collected that the practice time in judo seems to influence the outcome of the fights, considering that winners, despite having a lower average age present a significant superior mean time of practice in relation to the losers. In terms of the optimization of results as a function of experience, this seems to be one of the factors that distinguish novice athletes from those with more competitive experiences in judo (García et al., 2007).

Regarding the usual training regime, although the difference was not statistically significative in this study, it was observed that the winners presented a higher weekly training load than the losers. In these conditions, an athlete who dedicates a longer physical preparation time probably has a higher degree of training and a greater chance of competitive success when compared to individuals with a lower training load.

As for the values of the handgrip stregth motor tests (sum of both hands), lower back strength and flexibility, it was found that although the difference was not statistically significative, winners showed higher values than the losers in all tests. However, winners presented handgrip strength values considered good, while in the losers, such values were considered average (105-122 kgf, Caballero et al., 1996). 
In relation to the values of handgrip strength, the athlete's experience, combined with a longer training time, seems to be associated with an increase in muscle strength when compared to the beginner and higher ranked athletes (Costa et al., 2011; Lima et al., 2014). It should be emphasized that handgrip strength tends to be higher in relation to height and body mass increase (Franchini et al., 2000), a fact observed in the winners, since these are taller, heavier and have higher values of handgrip strength than losers.

In relation to the values of lumbar strength available in other studies such as Eichinger et al. (2016) evaluating non-athletes, found lumbar strength values (114 kgf) well below the mean of winners and losers in this study. Franchini et al. (2000) found values (151 Kgf) very similar to the winners of this study in juvenile judo athletes. Mansilla et al. (2000) identified in Spanish judo athletes, lumbar strength values (165kgf) 6\% higher than the values of winners in this study. In the question of flexibility (sit-and-reach test), winners and losers did not differ statistically from each other, with the average values of the winners being $10 \%$ lower (Castro et al. 2008) or $10 \%$ higher (Meloni et al. 2007) compared to other studies involving judo. Similar results in the flexibility test $(39.46 \mathrm{~cm})$ were found in jiu-jitsu athletes, demonstrating that the specific morphological characteristics of each modality depend on the requirements related to the context and the type of practice (Campos et al., 2015). In fact, both jiu-jitsu and judo are required, especially in the ground, for large amplitudes of body movement, under the active and passive forms of muscle stretching (Campos et al., 2015).

\section{Description of the fights}

In judo, attacks are organized to occur in different directions, depending on the opponent and the goals defined in the technical-tactical system of each fighter (Ando et al., 2016). In relation to the preparation and grabbing times, very close results and inferences were found by Marcon et al. (2010) which corroborate with the findings of the present investigation. However, unlike the present study, the temporal structure analysis was done using a specially designed computer program, so simulated judo matches were analysed, identifying preparation and grabbing times of around 4 seconds and 17 seconds, respectively. As for the mean values increased in the grabbing dispute, identified in losers in the second fight, it is possible to infer that this happened due to a smaller technicaltactical repertoire (Calmet \& Ahmaidi, 2004). Due to the longer time of practice, it is perceptible to think that winners present a greater number of techniques on the basis of experience, and thus to be more effective in the grabbing dispute (Miarka, 2014). As for the longer pause time presented by the losers in the two fights, it is possible that this is due to a strategy of fight. For Miarka (2014), the pause can represent a feedback opportunity for the athletes, being possible to use this time for technical-tactical readjustments of the fight. It should also be emphasized that the structure of a judo match has often been correlated with athletes' physical endurance (Ryszard et al., 2014). Thus, the change in the configuration of the fights in terms of pause and fight time on the ground may be a consequence of fatigue of the athletes or due to technical and tactical adjustments made from the time of pause, since in the first fight the winners presented values of ground fighting superiors to those of the losers, whereas in the second fight this fact reversed itself considerably.

As for the elements of the fight, the preliminary analysis showed that leg kicks were the most used, both by winners and losers, and such scams are statistically more significant in losers than in winners. It is worth mentioning that the preferred and most used judo projection techniques belong to the Ashi-waza (leg techniques) (Detanico et al., 2007). This suggests a strong preference for leg attacks, especially for heavier athletes (Ryszard et al., 2014), which is one of the probable justifications for the greater number of leg strikes presented by the losers, considering that they had higher BMI values, in relation to the winners. Coincidentally, there is a similarity between the prevalence of leg techniques and the height of the athletes, from this study with the results found by Detanico et 
al. (2007), where it was also observed a higher incidence of leg techniques for the same mean height $(173.8 \mathrm{~cm})$ of the athletes.

As for the reduction of arm strikes by the losers in the second fight, this may have happened because of a greater decline in isometric upper limb performance, compared to lower limb (Fernández et al., 2008). As for the outcome of the two fights, it was observed that $41 \%$ of the combats had the ippon outcome, with winners being more effective than losers. In a study developed by Witkowski et al. (2012), it was demonstrated that in male judo of the 2008 Beijing Olympics, out of a total of 303 bouts, $46.53 \%$ were decided by ippon, data very close to those of this study. In a similar research developed by Sterkowicz et al. (2007), involving video analysis (518 fights/64 hours duration) of Polish championships of judo, it was discussed the question of effectiveness and efficiency in the technical actions of judo. According to the aforementioned study, efficacy is a quantitative variable defined by arithmetic average scores, being expressed by the division of the total of points obtained by the number of effective techniques. Efficiency is already a qualitative variable defined by dividing the number of effective techniques by the total number of techniques multiplied by 100 . Therefore, it was observed that in the second fight, there was a decrease in the effectiveness of the ippon application by the winners; however, the efficiency of the attacks was maintained, triggering in the victory by other forms of outcome.

\section{Qualitative index of energy cost}

IQCE data revealed that winners spent less energy than losers in the first fight. Despite the greater time spent on ground fighting and the use of arm-strikes (greater energy expenditure), winners were more effective in the application of ippon. This has direct implication on the energy economy of the fight. Indeed, winners have preserved their energy reserves, unlike the losers who have spent far more energy than the winners in the use of leg strikes and fall defences. Probably these factors were responsible for the increase in attack and defence actions, respectively, and consequently for the increase of the IQCE.

In the second fight, there was an inversion of the energy cost, possibly due to a combat strategy change or fatigue effect. Thus, winners presented higher IQCE values than losers. It is worth noting that winners presented a higher incidence of throws of upper limbs than the losers in the first as well as in the second fights. Considering that such throws lead to a greater decline of the isometric strength in relation to the lower limbs (Fernández et al., 2008), and considering that the outcomes in the second fight pointed to other less energy-efficient means, such as the finalizations, for example, that happen mainly in function of upper limbs, it is possible to infer that such reasons justified the higher ICQE of the winners in the second fight.

In research with a sample close to this study, Franchini et al. (2008) studied three techniques of judo, morote-seoi-nage, harai-goshi and o-uchi-gari, in 12 judokas and showed that total energy (kJ) was higher for morote-seoi-nage (Arm technique). In a pioneering article aimed at estimating the contributions of energy systems during the simulations of 12 judo athletes, Julio et al. (2016), also proposed a calculation of the contribution of energy systems to estimate the energy expenditure of judo from resting $\mathrm{VO}_{2}$ (equivalent to $4.5 \mathrm{ml} \cdot \mathrm{kg} \cdot \mathrm{min}^{-1}$ ), confirming the importance of physiological indicators in the construction of energy estimates. This strategy confirms our concern in linking the IQEC to $\mathrm{VO}_{2}$ values, since it reinforces and expands the quantitative/qualitative relationship between the studies

Finally, it is worth mentioning that aerobic metabolism is responsible for providing the highest proportion of energy needed in a judo combat (Franchini et al., 2008; Julio et al, 2016). However, in judo, which generates scores and consequently determines the victory, are mainly attacks with projection techniques that require high short-term energy cost (ATP-PC system). Thus, the time spent in grab disputes and fhigth application requires muscle work, directly affecting the glycolytic demand (Julio et al., 2016), a fact fully demonstrated in this study through ICQE. 
Correlations between morphofunctional parameters, training regime and elements of the fight

The correlations found between the morphofunctional parameters are due to specific characteristics of the modalities. In a study conducted by Campos et al. (2015), it was found that the requirements related to the context and type of practice justify the correlation between BMI, handgrip strength and lumbar strength, and how much this may imply in the decrease of flexibility as a function of the increase in muscle mass (Campos et al. 2015). Thus, it is fully expected that the mean total BMI values found in this study result from muscle mass overweight gain, which is a morphological feature of the sport and may also be associated with increased in handgrip and lumbar strength.

As for the correlations between functional elements of the fight, morphofunctional parameters and training regime of the athletes, it is possible to infer that the configuration of the fights provided a close relation between the use of the throws, considering the experiences of the athletes, and their respective combat strategies. Of course, athletes who presented the highest indicators of hand grip strength, lumbar strength, and thoraco-lumbar flexibility probably had an increased advantage in footprint, trunk extension strength, and posterior thigh (hamstring) stretching relative to opponents with lower values in these indicators. Specifically, given the grabbing correlation (Kumi-Kata) and handgrip strength, it is worth highlight the important role of this association as a tactical technical component in judo. Grabbing is one of the determining technical factors in establishing a good control over the opponent's balance (Kajmovic et al., 2014). The same can be thought about the correlation of the leg strike with the result of the fight and the correlation of the time of the fight with the strikes of arms and legs. An effective grab is likely to allow an effective (arm or leg) attack culminating with fall and consequently, with the outcome of the fight. Regarding the correlation of pause time and practice time, it is possible to establish an association between these elements from the understanding that the pause time may have been used as a strategic element for more experienced athletes. It seems that the competitive environment emphasizes the differences between more experienced athletes and those with less training time (Garcia et al., 2007), that is, athletes with more competitive experience are able to better adapt their combat actions due to greater technical assets. This seems to be one of the factors that differentiate winners and losers in the results obtained in this study.

It is noticeable that the performance of a judo athlete should undergo eventual fluctuations during a competition (Campos et al., 2017). In this respect, it should be understood that in the face of various adversaries and different forms of confrontation, a wide variety of behaviours are likely to be delineated (Calmet \& Ahmaidi, 2004, Campos et al., 2017). However, any supplementary information that can detail competitive behaviour can be useful in raising performance indicators on winners and losers. Of course, the survey data in real situation tend to provide lower internal validity and some limitations due to the unpredictability of the environment. On the other hand, it is believed that the competitive situation and the impact of the cheer can also bring punctual elements, only identifiable in surveys of real combat situations in judo, and even so, according to Calmet and Ahmaidi (2004), it is very rare to see a judo athlete express all his experience during a single competition.

\section{CONCLUSIONS}

According to the data presented in the present investigation, it is concluded that: 1) The experience factor is determinant between winning or losing; 2) Leg techniques are more used between winners and losers, and losers use them more frequently; 3) There are different strategies between one fight and another subsequent; 4) The energy cost in judo depends on the configuration of the fights.

In summary, the results presented here revealed some performance indicators in judo that could only be detailed from in situ observations. This is the greatest merit of the study. It is believed that because of practicality, this type of knowledge approach can be incorporated into training programs in several 
areas involving combat sport, helping coaches and athletes in the search for solutions that can guide and rationalize the training process in relation to the determinants of performance in judo.

\section{Acknowledgments:}

Nothing to declare

\section{Conflict of interest:}

Nothing to declare

\section{Funding:}

Nothing to declare

\section{REFERÊNCIAS}

Ando, G. Y. U., Miarka, B., \& Pinto, M. N. N. (2016). Avaliação de análise técnico-tática em combates de judô por programa computacional por usuários com diferentes níveis de expertise. Journal of Physical Education, 27(1), e 2718.

Artioli, G. G., Bertuzzi, R. C., Roschel, H., Mendes, S. H., Lancha Jr, A. H., \& Franchini, E. (2012). Determining the contribution of the energy systems during exercise. Journal of Visualized Experiments, 61 (61), e3413, doi:10.3791/3413.

Caballero, J. A. R., Manso, J. M. G., Valdivielso, M. N., Ojeda, M. E. B., Campos, I. G., \& García, R. N. (1996). Algunos aspectos sobre la evaluación de la fuerza: test isometricos dinamometria y electromiografia. In Anais da X Jornadas Canarias de Traumatologia Y Cirugia Ortopédica (p. 166-170). Las Palmas de Gran Canária: Universidad de Las Palmas de Gran Canaria.

Calmet, M., \& Ahmaidi, S. (2004, September). Survey of the advantages obtained by judoka in competition according to their level of practice. Perceptual and Motor Skills, 99(1), 284-290, doi: 10.2466/PMS.99.5.284-290

Campos, I. S. L, Campos, Y., Campos, Y. S., Saraiva, A. R., \& Gouveia Jr, A. (2016). Ganhar e perder em esportes de combate: descrição de elementos determinantes. Revista brasileira Ciência e Movimento, 24(4), 156-167.

Campos, I. S. L., Campos, Y. S, \& Gouveia Jr, A. (2015). Características morfofuncionais e contexto esportivo. Revista brasileira de prescrição e fisiologia do Exercício, 9(56), 655-661.

Caporrino, F. A., Faloppa, F., Santos, J. B. G., Réssio, C., Soares, F. H. C., Nakachima, L. R., \& Segre, N. G. (1998). Estudo populacional da força de preensão palmar com dinamômetro Jamar. Revista Brasileira Ortopedia, 33(2), 150-154.

Castro, E. A., Venâncio, R. A. F., Doimo, L. A., \& Locatelli, J. (2008). Comparação entre dois métodos de treinamento para aprimoramento da flexibilidade em judocas da Associação Atlética Acadêmica - Luve/Ufv. Coleção Pesquisa em Educação Física, 7(2), 1981-4313.

Costa, R. P., \& Oliveira, F. B. (2011). Mensuração da força de preensão palmar em atletas de jiu-jitsu. VII Congresso Goiano de Ciências do Esporte. GoianiaGO.

Detanico, D., \& Santos, S. G. (2012). Avaliação específica no judô: uma revisão de métodos. Revista Brasileira Cineantropometria e Desempenho Humano, 14(6), 738-748.

Drigo, A. J., Amorim, A. R., Martins, C. J., \& Molina, R. (1996). Demanda metabólica em lutas de projeção e de solo no judô: estudo pelo lactato sanguíneo. Motriz, 2(2), 80.

Eichinger, F. L. F., Soares, A. V., Júnior, J. M. C., Gevaerd, M. S., Domenech, S. C., \& Júnior, N. G. B. (2016). Dinamometria lombar: um teste funcional para o tronco. Revista Brasileira Medicina Trabalho, 14(2), 120-126.

Fernández, E. C., Soler, E. I., \& Calvo, X. D. (2008). Análise dos efeitos agudos do enfrentamento no judô, através do estudo da associação entre parâmetros metabólicos e mecânicos. Fitness $e$ Performance Journal, 7(4) 229-38.

França, N. M., \& Vívolo, M. A. (1994). Medidas Antropométricas. In V. K. R. Matsudo (Org.) Testes em ciências do exporte (pp. 19-32). São Caetano do Sul: Burti

Franchini, E., Bertuzzi, R. C. M., Degaki, E., Mello, F. C., Fiebig, E., \& Silva, W. F. F. L. (2008). Energy expenditure in different judo throwing techniques. Source: Proceedings of first joint international pre-Olympic conference of sports science and sports engineering. Bio-mechanics and sports engineering, 2, 55-60.

Franchini, E., Takito, M. Y., \& Kiss, M. A. P. D. (2000). Somatótipo, composição corporal e força isométrica em diferentes períodos do treinamento em atletas de judô juvenis. Revista Treinamento Desportivo, 5(2), 4-10.

Franchini, F., Sterkowicz, S., Szmatlan-Gabrys, U., Gabrys, T., \& Garnys, M. (2011). Energy System contributions to the Special Judo Fitness Test. International Journal of Sports Physiology and Performance, 6(3), 334-343.

García, J. M. G., Valdivielso, F. N., Ravé, J. M. G., \& Bibiana, C. R. (2007). Paradigma experto-novato: Análisis diferencial de la pérdida de consistencia del Tokui Waza en Judo bajo situación específica de fatiga. Revista internacional de Ciencias del deporte, 9(3), 12-29, doi:10.5232/ricyde2007.00902

Gariod, L., Favre-Juvin, A., Novel, U., \& Rossi, A. (1995). Évaluation du profil énergétique des judokas par spectroscopie RMN du. Sciences \& sports, 10(4), 201-207.

Guedes, D. P., \& Guedes, J. E. R. P. (2006). Manual Prático para Avaliação em Educação Física. Barueri: Manole.

Julio, U. F. (2015). Aptidão física, ações técnicas e resposta fisiológicas durante a luta de judô (Tese de 
Doutorado em Educação Física e Esporte), Universidade de São Paulo, São Paulo.

Julio, U. F., Panissa, V. L. G., Esteves, J. V., Cury, R. L., Agostinho, M. F., \& Franchini, E. (2017). EnergySystem Contributions to Simulated Judo Matches. International Journal of Sports Physiology and Performance, 12(5), 676-683. https://doi.org/10.1123/ijspp.2015-0750

Kajmovic, H., Rado, I., Mekic, A., Crnogorac, B., \& Colakhodzic, E. (2014). Differences in gripping configurations during the execution of throwing techniques between male and female cadets at the European Judo Championship. Archives of budo, science of martial arts, 10, 141-146.

Lehner, P. N. (1996) Handbook of ethological methods (2 ${ }^{\text {nd }}$ Ed.). Cambridge University Press.

Lima, M. C., Kubota, L. M., Monteiro, C. B. M., Baldan, C. S., \& Pompeu, J. E. (2014). Força de preensão manual em atletas de judô. Revista Brasileira Medicina e Esporte, 20(3), 210-213.

Mansilla, F. M., Villa, V. J., García, L. J., \& López, R. C. (2000). Comparación de diferentes manifestaciones de fuerza y flexibilidad entre luchadores de lucha leonesa y judocas. I Congreso Internacional de la Asociación Española de Ciencias del Deporte. Cáceres.

Marcon, G., Franchini, F., Jardim, J. R., \& Neto, T. L. B. (2010). Structural Analysis of Action and Time in Sports: Judo. Journal of quantitative analysis in sports, 6(4). doi: 10.2202/1559-0410.1226

Meloni, P. H. S., Venâncio, R. A, Locatelli, J., Milani, N. S., \& Doimo, L. A. (2007). Análise morfológica dos atletas de judô participantes do campeonato mineiro - VIÇOSA-MG. Coleção Pesquisa em Educação Física, 6, 95-102.
Miarka, B. (2014). Modelagem das interações técnicas e táticas em atletas de judô: comparações entre categorias, nivel competitivo e resultados de combate no circuito mundial de judô dos jogos olímpicos de Londres (Tese de Doutorado em Educação Física e Esporte). Universidade de São Paulo, São Paulo.

Ryszard, P., Marek, A., Agnieszka, K., \& Wieslaw, B. (2014). The course of the judo fight in the heaviest category $(+100 \mathrm{~kg})$ seen from the perspective of attacks in the standing position, based on the Olympic Games in London 2012. Journal of Martial Arts Anthropology, 14(1), 63-71.

Santos, S. O. D. (2013). A integração oriente-ocidente e os fundamentos do judô educativo (Dissertação de mestrado em Educação). Faculdade de humanidades e Direito da Universidade Metodista de São Paulo, São Bernardo do Campo.

Sterkowicz, S., Lech, G., \& Almansba, R. (2007). The course of fight and the level of sports achievements in judô. Archives of Budo, 3, 72-78.

Watson, B. N. (2011). Memórias de Jigoro Kano: o ensino da história do judô. São Paulo: Cultrix.

Wilson, G.V., \& Kerr, J.H. (1999). Affective responses to success and failure: a study of winning and losing in competitive rugby. Personality and Individual Differences, 27(1), 85-99.

Witkowski, k., Maśliński, J., \& Kotwica, T. (2012). Analysis of fighting actions of judo competitors on the basis of the men's tournament during the 2008 Olympic Games in Beijing. Journal of Combat Sports and Martial Arts, 3(2), 121-129.

World Health Organization. (2003). Diet, Nutrition and the Prevention of Chronic Disease. Report 8. Núm. 916. Geneva: WHO. 